\title{
Assessment of genetic factors for type 2 diabetes mellitus
}

\author{
YOSHIJI YAMADA ${ }^{1,2}$, HITOSHI MATSUO $^{3}$, TOMONORI SEGAWA ${ }^{3}$, SACHIRO WATANABE $^{3}$, \\ KIMIHIKO KATO ${ }^{4}$, TAKASHI KAMEYAMA ${ }^{5}$, KIYOSHI YOKOI ${ }^{4}$, SAHOKO ICHIHARA ${ }^{1}$, \\ NORIFUMI METOKI ${ }^{6}$, HIDEMI YOSHIDA ${ }^{7}, \mathrm{KEI} \mathrm{SATOH}^{7}$ and YOSHINORI NOZAWA ${ }^{2}$ \\ ${ }^{1}$ Department of Human Functional Genomics, Life Science Research Center, Mie University, Tsu; \\ ${ }^{2}$ Gifu International Institute of Biotechnology, Kakamigahara; ${ }^{3}$ Department of Cardiology, Gifu Prefectural \\ Gifu Hospital, Gifu; ${ }^{4}$ Department of Cardiovascular Medicine, and ${ }^{5}$ Department of Neurology, Gifu Prefectural \\ Tajimi Hospital, Tajimi; ${ }^{6}$ Department of Internal Medicine, Reimeikyo Rehabilitation Hospital, Minamitsugaru; \\ ${ }^{7}$ Department of Vascular Biology, Institute of Brain Science, Hirosaki University School of Medicine, Hirosaki, Japan
}

Received February 28, 2006; Accepted April 27, 2006

\begin{abstract}
The purpose of the present study was to identify gene polymorphisms for reliable assessment of genetic factors for type 2 diabetes mellitus. The study population comprised 4853 unrelated Japanese individuals (2688 men, 2165 women), including 1489 subjects with type 2 diabetes mellitus (969 men, 520 women) and 3364 controls (1719 men, 1645 women). The genotypes for 148 polymorphisms of 124 candidate genes were determined with a method that combines polymerase chain reaction and sequence-specific oligonucleotide probes with suspension array technology. Sixteen polymorphisms were related $(\mathrm{p}<0.05)$ to the prevalence of type 2 diabetes mellitus as determined by the chi-square test. Multivariable logistic regression analysis with adjustment for age, sex, and the prevalence of smoking revealed that, among these polymorphisms, the $-603 \mathrm{~A} \rightarrow \mathrm{G}$ polymorphism of the gene for coagulation factor III $(F 3)$ was significantly $(\mathrm{p}<0.001)$ associated with the prevalence of type 2 diabetes mellitus, with the $-603 \mathrm{G}$ allele representing a risk factor for this condition. A stepwise forward selection procedure demonstrated that $F 3$ genotype (GG versus AA + AG) significantly $(\mathrm{p}<0.001)$ and independently affected the prevalence of type 2 diabetes mellitus. Genotype for $F 3$ may prove reliable for assessment of genetic factors for type 2 diabetes mellitus. Determination of the genotype for this gene may contribute to personalized prevention of this condition.
\end{abstract}

\section{Introduction}

Type 2 diabetes mellitus is a multifactorial disease with a substantial genetic component that is thought to be polygenic

Correspondence to: Dr Yoshiji Yamada, Department of Human Functional Genomics, Life Science Research Center, Mie University, 1577 Kurima-machiya, Tsu, Mie 514-8507, Japan

E-mail: yamada@gene.mie-u.ac.jp

Key words: polymorphism, genetics, diabetes mellitus, coagulation factor III, tissue factor, thromboplastin in nature. A combination of genes thus likely influences the underlying level of glucose intolerance in a population and thereby contributes to the overall susceptibility to type 2 diabetes mellitus. Although genetic linkage analyses (1-5) and association studies (6-10) have implicated several loci and candidate genes in predisposition to type 2 diabetes mellitus, the genes that contribute to genetic susceptibility to this condition remain to be identified definitively. In addition, given the ethnic differences in lifestyle and environmental factors as well as in genetic background, it is important to examine polymorphisms related to type 2 diabetes mellitus in each ethnic group.

We have now performed a large-scale association study for 148 candidate gene polymorphisms and type 2 diabetes mellitus in 4853 Japanese individuals. The purpose of the present study was to identify gene polymorphisms that confer susceptibility to type 2 diabetes mellitus and thereby to contribute to the personalized prevention of this condition.

\section{Materials and methods}

Study population. The study population comprised 4853 unrelated Japanese individuals (2688 men, 2165 women) who either visited outpatient clinics of or were admitted to one of the participating hospitals (Gifu Prefectural Gifu, Tajimi, and Gero Hotspring Hospitals; Hirosaki University Hospital; Reimeikyo Rehabilitation Hospital; and Yokohama General Hospital) between October 2002 and March 2005. The 1489 subjects (969 men, 520 women) with type 2 diabetes mellitus had a fasting plasma glucose concentration of $\geq 6.93 \mathrm{mmol} / \mathrm{l}$ $(126 \mathrm{mg} / \mathrm{dl})$ or a blood hemoglobin $\mathrm{A}_{1 \mathrm{c}}\left(\mathrm{HbA}_{1 \mathrm{c}}\right)$ of $\geq 6.5 \%$ (or both) or were taking antidiabetes medication. Type 2 diabetes mellitus was defined according to the criteria accepted by the World Health Organization and described previously $(11,12)$. Individuals with type 1 diabetes mellitus, with maturity-onset diabetes of the young, with other metabolic or endocrinologic diseases, or with severe liver or renal dysfunction were excluded from the study. Individuals taking drugs that cause secondary diabetes mellitus were also excluded.

The control subjects comprised a total of 3364 individuals (1719 men, 1645 women) who visited the outpatient clinics 
Table I. Characteristics of the 4853 study subjects.

\begin{tabular}{|c|c|c|}
\hline Characteristic & $\begin{array}{c}\text { Type } 2 \\
\text { diabetes mellitus }\end{array}$ & Controls \\
\hline No. of subjects & 1489 & 3364 \\
\hline Age (years) & $63.7 \pm 11.5$ & $63.8 \pm 11.8$ \\
\hline Sex (male/female, \%) & $65.1 / 34.9^{\mathrm{a}}$ & $51.1 / 48.9$ \\
\hline BMI $\left(\mathrm{kg} / \mathrm{m}^{2}\right)$ & $23.7 \pm 3.4^{\mathrm{a}}$ & $23.3 \pm 2.8$ \\
\hline Current or former smoker $(\%)$ & $20.8^{\mathrm{a}}$ & 16.2 \\
\hline Hypertension (\%) & $77.2^{\mathrm{a}}$ & 49.6 \\
\hline Hypercholesterolemia (\%) & $51.6^{\mathrm{a}}$ & 32.5 \\
\hline Fasting plasma glucose $(\mathrm{mmol} / \mathrm{l})$ & $10.2 \pm 4.4^{\mathrm{a}}$ & $5.2 \pm 0.7$ \\
\hline $\mathrm{HbA}_{1 \mathrm{c}}(\%)$ & $7.8 \pm 2.2^{\mathrm{a}}$ & $5.3 \pm 0.4$ \\
\hline \multicolumn{3}{|c|}{$\begin{array}{l}\text { Data for age and body mass index }(\mathrm{BMI}) \text { are means } \pm \text { SD. Smoker: } \\
\text { smoking of } \geq 10 \text { cigarettes daily. Hypertension: systolic blood pressure } \\
\text { of } \geq 140 \mathrm{mmHg} \text { or diastolic blood pressure of } \geq 90 \mathrm{mmHg} \text { (or both), } \\
\text { or taking antihypertensive medication. Hypercholesterolemia: serum } \\
\text { total cholesterol of } \geq 5.72 \mathrm{mmol} / \mathrm{l}(220 \mathrm{mg} / \mathrm{dl} \text { ) or taking lipid-lowering } \\
\text { medication. }{ }^{\mathrm{a} p}<0.001 \text { versus controls. }\end{array}$} \\
\hline
\end{tabular}

of participating hospitals for an annual health checkup. They had a fasting plasma glucose concentration of $<6.05 \mathrm{mmol} / \mathrm{l}$ $(110 \mathrm{mg} / \mathrm{dl})$ and a blood $\mathrm{HbA}_{1 \mathrm{c}}$ of $<5.6 \%$, and they had no history of diabetes mellitus or of taking antidiabetes medication. The study protocol complied with the Declaration of Helsinki and was approved by the Committees on the Ethics of Human Research of Mie University School of Medicine, Hirosaki University School of Medicine, Gifu International Institute of Biotechnology, and participating hospitals, and written informed consent was obtained from each participant.

Selection of polymorphisms. With the use of public databases, we selected 124 candidate genes that have been characterized and were suggested to be potentially associated with type 2 diabetes mellitus on the basis of a comprehensive overview of the function of pancreatic $B$ cells, peripheral insulin sensitivity, hepatic glucose production, lipid and adipose tissue metabolism, and other metabolic factors as well as of regulation of blood pressure and endocrine function, vascular biology, monocyte-macrophage biology, lymphocyte and other leukocyte biology, coagulation and fibrinolysis systems, and platelet function. We further selected for analysis 148 polymorphisms of these genes, most of which are located in the promoter region, exons, or splice donor or acceptor sites of introns and might therefore be expected to affect the function or expression of the encoded protein (Supplementary Table I).

Genotyping of polymorphisms. Venous blood (7 ml) was collected into tubes containing $50 \mathrm{mmol} / \mathrm{l}$ EDTA (disodium salt), and genomic DNA was isolated with a kit (Genomix; Talent, Trieste, Italy). Genotypes of the 148 polymorphisms were determined (G\&G Science, Fukushima, Japan) by a method that combines polymerase chain reaction and sequencespecific oligonucleotide probes with suspension array technology (Luminex, Austin, TX, USA). Primers, probes, and
Table II. Polymorphisms related $(\mathrm{p}<0.05)$ to type 2 diabetes mellitus as determined by the chi-square test.

\begin{tabular}{lll}
\hline Gene symbol & Polymorphism & p-value \\
\hline F3 & $-603 \mathrm{~A} \rightarrow \mathrm{G}$ & 0.0005 \\
PON1 & $532 \mathrm{~A} \rightarrow \mathrm{G}$ (Arg160Gly) & 0.0026 \\
ACE & $-240 \mathrm{~A} \rightarrow \mathrm{T}$ & 0.0070 \\
CD14 & $-260 \mathrm{C} \rightarrow \mathrm{T}$ & 0.0074 \\
ABCA1 & $2583 \mathrm{~A} \rightarrow \mathrm{G}$ (Ile823Met) & 0.0079 \\
AP2M1 & $62 \mathrm{G} \rightarrow \mathrm{T}$ & 0.0162 \\
MMP12 & $-82 \mathrm{~A} \rightarrow \mathrm{G}$ & 0.0231 \\
THBS2 & $3949 \mathrm{~T} \rightarrow \mathrm{G}$ & 0.0235 \\
PPP1R3A & $2711 \mathrm{G} \rightarrow \mathrm{T}$ (Tyr905Asp) & 0.0312 \\
F7 & $11,496 \mathrm{G} \rightarrow \mathrm{A}$ (Arg353Gln) & 0.0314 \\
PKD1-like & $\mathrm{G} \rightarrow \mathrm{A}(\mathrm{Gly} 243$ Asp) & 0.0326 \\
PECAM1 & $2201 \mathrm{G} \rightarrow \mathrm{A}(\mathrm{Gly} 670 A r g)$ & 0.0352 \\
UTS2 & $347 \mathrm{G} \rightarrow \mathrm{A}$ (Ser89Asn) & 0.0401 \\
CX3CR1 & $926 \mathrm{C} \rightarrow \mathrm{T}$ (Thr280Met) & 0.0410 \\
AKAP10 & $2073 \mathrm{~A} \rightarrow \mathrm{G}$ (Ile646Val) & 0.0420 \\
IPF1 & $-180 / 3 \mathrm{G} \rightarrow 4 \mathrm{G}$ & 0.0457 \\
\hline
\end{tabular}

other conditions for genotyping are shown in Supplementary Table II. The detailed genotyping methodology was described previously (13).

Statistical analysis. Clinical data were compared between subjects with type 2 diabetes mellitus and controls by the unpaired Student's t-test. Qualitative data were compared by the chi-square test. Allele frequencies were estimated by the gene counting method, and the chi-square test was used to identify departures from Hardy-Weinberg equilibrium. The genotype distribution of each autosomal polymorphism was compared between subjects with type 2 diabetes mellitus and controls by the chi-square test $(3 \times 2)$; for polymorphisms on the $\mathrm{X}$ chromosome, allele frequencies were compared by the chi-square test $(2 \times 2)$. Polymorphisms related to type 2 diabetes mellitus $(\mathrm{p}<0.05)$ were examined by multivariable logistic regression analysis with adjustment for covariates, with type 2 diabetes mellitus as a dependent variable and independent variables including age, sex $(0=$ woman, $1=$ man $)$, smoking status $(0=$ nonsmoker, $1=$ smoker $)$, and genotype of each polymorphism. Each genotype was assessed according to dominant, recessive, and two additive (additive 1 and 2) genetic models, and the p-value, odds ratio, and $95 \%$ confidence interval were calculated. Each genetic model comprised two groups: the combined group of variant homozygotes and heterozygotes versus wild-type homozygotes for the dominant model; variant homozygotes versus the combined group of wild-type homozygotes and heterozygotes for the recessive model; heterozygotes versus wild-type homozygotes for the additive 1 model; and variant homozygotes versus wild-type homozygotes for the additive 2 model. We also performed a stepwise forward selection procedure to examine the effects of genotypes as well as of other covariates on type 2 diabetes 
Table III. Multivariable logistic regression analysis of polymorphisms related to type 2 diabetes mellitus.

\begin{tabular}{|c|c|c|c|c|c|c|c|c|}
\hline \multirow{2}{*}{$\begin{array}{l}\text { Gene } \\
\text { symbol }\end{array}$} & \multirow[t]{2}{*}{ Polymorphism } & \multicolumn{2}{|r|}{ Dominant } & Recessive & \multicolumn{2}{|c|}{ Additive 1} & \multicolumn{2}{|c|}{ Additive 2} \\
\hline & & $\mathrm{p}$-value & OR $(95 \% \mathrm{CI})$ & p-value OR $(95 \% \mathrm{CI})$ & $\mathrm{p}$-value & OR $(95 \% \mathrm{CI})$ & p-value & OR $(95 \% \mathrm{CI})$ \\
\hline$F 3$ & $-603 \mathrm{~A} \rightarrow \mathrm{G}$ & 0.8103 & & $\mathbf{0 . 0 0 0 1} 1.75(1.32-2.33)$ & 0.1574 & & 0.0003 & $1.70(1.27-2.26)$ \\
\hline PON1 & $532 \mathrm{~A} \rightarrow \mathrm{G}$ (Arg160Gly) & 0.0039 & $1.28(1.08-1.52)$ & 0.2203 & 0.0020 & $1.31(1.10-1.55)$ & 0.2451 & \\
\hline$A C E$ & $-240 \mathrm{~A} \rightarrow \mathrm{T}$ & 0.0042 & $1.20(1.06-1.37)$ & 0.0575 & 0.0169 & $1.18(1.03-1.35)$ & 0.0077 & $1.30(1.07-1.57)$ \\
\hline$C D 14$ & $-260 \mathrm{C} \rightarrow \mathrm{T}$ & 0.0040 & $1.25(1.07-1.46)$ & 0.2578 & 0.0077 & $1.24(1.06-1.46)$ & 0.0105 & $1.26(1.06-1.50)$ \\
\hline$A B C A 1$ & $2583 \mathrm{~A} \rightarrow \mathrm{G}(\mathrm{Ile} 823 \mathrm{Met})$ & 0.0344 & $1.22(1.02-1.46)$ & $0.00401 .20(1.06-1.36)$ & 0.2104 & & 0.0050 & $1.32(1.09-1.61)$ \\
\hline$A P 2 M 1$ & $62 \mathrm{G} \rightarrow \mathrm{T}$ & 0.0813 & & $0.00441 .35(1.10-1.65)$ & 0.3746 & & 0.0029 & $1.38(1.12-1.71)$ \\
\hline MMP12 & $-82 \mathrm{~A} \rightarrow \mathrm{G}$ & 0.6391 & & 0.5840 & 0.4346 & & 0.5843 & \\
\hline THBS2 & $3949 \mathrm{~T} \rightarrow \mathrm{G}$ & 0.0137 & $1.22(1.04-1.42)$ & 0.0736 & 0.0351 & $1.19(1.01-1.40)$ & 0.0578 & \\
\hline PPP1R3A & $2711 \mathrm{G} \rightarrow \mathrm{T}$ (Tyr905Asp) & 0.0341 & $1.28(1.02-1.62)$ & 0.6659 & 0.0183 & $1.34(1.05-1.70)$ & 0.0766 & \\
\hline$F 7$ & $11,496 \mathrm{G} \rightarrow \mathrm{A}(\mathrm{Arg} 353 \mathrm{Gln})$ & 0.0226 & $0.80(0.65-0.97)$ & 0.6628 & 0.0167 & $0.78(0.64-0.95)$ & 0.7049 & \\
\hline PKD1-like & $\mathrm{G} \rightarrow \mathrm{A}($ Gly243Asp $)$ & 0.0472 & $0.48(0.22-0.95)$ & & 0.0472 & $0.48(0.22-0.95)$ & & \\
\hline PECAM1 & $2201 \mathrm{G} \rightarrow \mathrm{A}(\mathrm{Gly} 670 \mathrm{Arg})$ & 0.0442 & $1.17(1.00-1.36)$ & 0.3118 & 0.0134 & $1.23(1.04-1.44)$ & 0.4209 & \\
\hline UTS2 & $347 \mathrm{G} \rightarrow \mathrm{A}($ Ser89Asn $)$ & 0.1204 & & 0.1228 & 0.0393 & $1.15(1.01-1.31)$ & 0.2283 & \\
\hline CX3CR1 & 926C $\rightarrow \mathrm{T}$ (Thr280Met) & 0.0113 & $1.31(1.06-1.62)$ & 0.9138 & 0.0103 & $1.32(1.07-1.63)$ & 0.9365 & \\
\hline AKAP10 & $2073 \mathrm{~A} \rightarrow \mathrm{G}($ Ile646Val $)$ & 0.0414 & $0.87(0.77-0.99)$ & 0.0838 & 0.1056 & & 0.0537 & \\
\hline$I P F 1$ & $-180 / 3 \mathrm{G} \rightarrow 4 \mathrm{G}$ & 0.0316 & $0.85(0.74-0.99)$ & 0.1380 & 0.0806 & & 0.0254 & $0.82(0.69-0.98)$ \\
\hline
\end{tabular}

Multivariable logistic regression analysis was performed with adjustment for age, sex, and the prevalence of smoking. OR, odds ratio; CI, confidence interval. p-values of $<0.001$ are shown in bold.

mellitus. The levels for inclusion in and exclusion from the model were 0.25 and 0.1 , respectively. Given the multiple comparisons of genotypes with type 2 diabetes mellitus, we adopted a strict criterion $(\mathrm{p}<0.001)$ for statistical significance of association in order to avoid type I error. For other clinical background data, a p-value of $<0.05$ was considered statistically significant. Statistical significance was examined by two-sided tests, and statistical analyses were performed with JMP version 5.1 software (SAS Institute, Cary, NC, USA).

\section{Results}

The characteristics of the 4853 study subjects are shown in Table I. The frequency of male subjects, body mass index, and the prevalence of smoking, hypertension, and hypercholesterolemia were greater for subjects with type 2 diabetes mellitus than for controls. Comparison of genotype distributions with the chi-square test revealed that 16 polymorphisms were related $(p<0.05)$ to the prevalence of type 2 diabetes mellitus (Table II). These polymorphisms were further analyzed for their possible association with type 2 diabetes mellitus.

Multivariable logistic regression analysis with adjustment for age, sex, and smoking status revealed that the $-603 \mathrm{~A} \rightarrow \mathrm{G}$ polymorphism of the coagulation factor III gene $(F 3$, recessive and additive 2 models) was significantly $(\mathrm{p}<0.001)$ associated with the prevalence of type 2 diabetes mellitus, with the $-603 \mathrm{G}$ allele being a risk factor for this condition (Table III). The genotype distributions for all 16 polymorphisms related to type 2 diabetes are shown in Table IV; those in control subjects were in Hardy-Weinberg equilibrium.
Finally, we performed a stepwise forward selection procedure to examine the effects of genotypes for these polymorphisms, age, sex, and smoking status on type 2 diabetes mellitus (Table V). Sex and F3 genotype (recessive model), in descending order of statistical significance $(p<0.001)$, independently influenced the prevalence of type 2 diabetes mellitus.

\section{Discussion}

We have examined the possible relationships of 148 polymorphisms in 124 candidate genes to type 2 diabetes mellitus. Our large-scale association study with 4853 individuals revealed that the $-603 \mathrm{~A} \rightarrow \mathrm{G}$ polymorphism of $F 3$ was significantly associated with the prevalence of type 2 diabetes mellitus in the Japanese population. The chromosomal region containing $F 3$ (1p22-21) has not previously been linked to type 2 diabetes mellitus in the Japanese population (14-16), and $F 3$ itself has not been identified as a candidate gene for predisposition to this condition.

F3 (tissue factor or tissue thromboplastin) is a $47-\mathrm{kDa}$ transmembrane glycoprotein, which, in response to binding of factor VIIa, activates coagulation factor X by converting it to factor $\mathrm{Xa}$ and thereby initiates the extrinsic coagulation cascade. Although F3 is normally not expressed in circulating leukocytes or endothelial cells, transcription of $F 3$ is induced in these cells by proinflammatory cytokines, growth factors, shear forces, or balloon injury of the vessel wall (17). The abundance of F3 mRNA is increased in several tissues, including adipose tissue, of obese mice compared with those 
Table IV. Genotype distributions of polymorphisms related to type 2 diabetes mellitus.

\begin{tabular}{|c|c|c|}
\hline $\begin{array}{l}\text { Gene } \\
\text { symbol }\end{array}$ & Polymorphism & $\begin{array}{l}\text { Type } 2 \text { diabetes Controls } \\
\text { mellitus }\end{array}$ \\
\hline
\end{tabular}

\begin{tabular}{rrrr}
\hline$F 3 \quad-603 \mathrm{~A} \rightarrow \mathrm{G}$ & & \\
$\mathrm{AA}$ & 64.7 & 64.8 \\
$\mathrm{AG}$ & 29.3 & 31.6 \\
$\mathrm{GG}$ & 6.0 & 3.5
\end{tabular}

PON1 $532 \mathrm{~A} \rightarrow \mathrm{G}($ Arg 160Gly)

AA

83.1

86.4

AG

16.7

GG

0.2

ACE

$$
-240 \mathrm{~A} \rightarrow \mathrm{T}
$$

AA

AT

TT

36.8

48.3

14.9

CD14

$-260 \mathrm{C} \rightarrow \mathrm{T}$
$\mathrm{CC}$
$\mathrm{CT}$
$\mathrm{TT}$

ABCAl

$2583 \mathrm{~A} \rightarrow \mathrm{G}$ (Ile823Met)

AA

AG

GG

AP2MI

$62 \mathrm{G} \rightarrow \mathrm{T}$

GG

GT

TT

MMP12

AA

AG

GG

THBS2

$3949 \mathrm{~T} \rightarrow \mathrm{G}$
TT
TG
GG

PPP1R3A 2711G $\rightarrow$ T (Tyr905Asp)

GG

GT

TT

F7

$11,496 \mathrm{G} \rightarrow \mathrm{A}(\mathrm{Arg} 353 \mathrm{Gln})$

GG

89.6

GA

AA

9.9

0.5

79.7

18.7

1.6

82.5

$\begin{array}{rr}7.3 & 9.4 \\ 42.6 & 40.4 \\ 50.2 & 50.2 \\ & \\ 89.6 & 87.1 \\ 9.9 & 12.5 \\ 0.5 & 0.4\end{array}$

PKD1-like $\quad \mathrm{G} \rightarrow \mathrm{A}$ (Gly243Asp)

GG

GA

99.4

0.6

AA
16.6

0.9

0.5

41.4

45.7

12.9

23.5

48.6

28.0

14.9

46.7

38.4

50.5

41.0

8.5

95.9

4.1

0

IPF1

IPF 1

\begin{tabular}{ccrr} 
& $\mathrm{AA}$ & 66.2 & 62.8 \\
& $\mathrm{AG}$ & 30.4 & 32.7 \\
$\mathrm{GG} 1$ & 3.4 & 4.5 \\
& $-180 / 3 \mathrm{G} \rightarrow 4 \mathrm{G}$ & & \\
& $3 \mathrm{G} 3 \mathrm{G}$ & 25.3 & 22.2 \\
& $3 \mathrm{G} 4 \mathrm{G}$ & 49.3 & 50.4 \\
& $4 \mathrm{G} 4 \mathrm{G}$ & 25.4 & 27.4 \\
\hline
\end{tabular}

AKAP10 2073A $\rightarrow$ G $($ Ile646Val $)$

\begin{tabular}{ccrr} 
& $\mathrm{AA}$ & 66.2 & 62.8 \\
& $\mathrm{AG}$ & 30.4 & 32.7 \\
$\mathrm{GG} 1$ & 3.4 & 4.5 \\
& $-180 / 3 \mathrm{G} \rightarrow 4 \mathrm{G}$ & & \\
& $3 \mathrm{G} 3 \mathrm{G}$ & 25.3 & 22.2 \\
& $3 \mathrm{G} 4 \mathrm{G}$ & 49.3 & 50.4 \\
& $4 \mathrm{G} 4 \mathrm{G}$ & 25.4 & 27.4 \\
\hline
\end{tabular}

CX3CR1 $926 \mathrm{C} \rightarrow \mathrm{T}(\mathrm{Thr} 280 \mathrm{Met})$

$\begin{array}{lrr}\text { CC } & 89.8 & 92.0 \\ \text { CT } & 10.1 & 7.9 \\ \text { TT } & 0.1 & 0.2\end{array}$

of lean mice $(18,19)$, suggesting that hyperinsulinemia associated with insulin-resistant states, such as obesity and type 2 diabetes mellitus, may induce $F 3$ expression locally in multiple tissues.

The expression of F3 was shown to be higher in monocytes from individuals with diabetes mellitus than in those from nondiabetic controls (20). Although similar numbers of cellderived microparticles were found in both individuals with well-controlled, uncomplicated type 2 diabetes mellitus and nondiabetic controls, a higher proportion of microparticles derived from $\mathrm{T}$ helper cells, granulocytes, and platelets exposed F3 in the former group (21). The plasma concentration of F3 was also higher in individuals with type 2 diabetes mellitus than in nondiabetic controls; furthermore, it was higher in diabetic individuals with cardiovascular disease than in those without this condition, suggesting that $\mathrm{F} 3$ levels are related to vascular complications $(22,23)$. Indeed, the $-603 \mathrm{~A} \rightarrow \mathrm{G}$ polymorphism of $F 3$ has been associated with myocardial infarction, with the $-603 \mathrm{G}$ allele being a risk factor for this condition (24). Moberg et al (25) showed that an instant blood-mediated inflammatory reaction (IBMIR) occurs frequently during transplantation of pancreatic islets. Given that F3 is produced and secreted by the endocrine cells of islets of Langerhans and that the IBMIR is inhibited by antibodies to F3 and site-inactivated factor VIIa in vitro, these researchers concluded that the IBMIR is triggered by 
Table V. Effects of genotypes and other characteristics on type 2 diabetes mellitus as determined by a stepwise forward selection procedure.

\begin{tabular}{lrc}
\hline Variable & p-value & $\mathrm{R}^{2}$ \\
\hline Sex & $<0.0001$ & 0.0138 \\
F3 (GG versus AA + AG) & 0.0002 & 0.0024 \\
ACE (TT + AT versus AA) & 0.0031 & 0.0015 \\
PON1 (GG + AG versus AA) & 0.0040 & 0.0014 \\
CD14 (TT + CT versus CC) & 0.0040 & 0.0014 \\
AP2MI (TT versus GG + GT) & 0.0043 & 0.0013 \\
ABCA1 (GG versus AA + AG) & 0.0061 & 0.0012 \\
CX3CRI (TT + CT versus CC) & 0.0099 & 0.0012 \\
IPF1 (4G4G + 3G4G versus 3G3G) & 0.0194 & 0.0009 \\
THBS2 (GG + TG versus TT) & 0.0231 & 0.0009 \\
F7 (AA + GA versus GG) & 0.0243 & 0.0008 \\
PPP1R3A (TT + GT versus GG) & 0.0262 & 0.0008 \\
PECAMI (AA + GA versus GG) & 0.0346 & 0.0008 \\
PKD1-like (AA + GA versus GG) & 0.0379 & 0.0007 \\
\hline
\end{tabular}

F3. These observations suggest that inhibition of F3 activity may be beneficial during clinical islet transplantation.

Induction of F3 expression occurs at a transcriptional level through the action of cell type-specific promoters. Transcriptional induction of $F 3$ is mediated by AP- 1 and $\mathrm{NF}-\kappa \mathrm{B}$ sites in endothelial and monocytic cells and by Egr-1 and Sp1 sites in epithelial and smooth muscle cells and monocytes (17). Various promoter polymorphisms of $F 3$ have been described: four polymorphisms $(-1812 \mathrm{C} \rightarrow \mathrm{T},-1322 \mathrm{C} \rightarrow \mathrm{T}$, $-1208 \mathrm{D} / \mathrm{I}$, and $-603 \mathrm{~A} \rightarrow \mathrm{G})$ are in linkage disequilibrium and two other polymorphisms $(-1442 \mathrm{G} \rightarrow \mathrm{C}$ and $-21 \mathrm{C} \rightarrow \mathrm{T})$ are rare (26). Individuals homozygous for the D allele of the deletion/ insertion (D/I) polymorphism at nucleotide position -1208 were found to have a lower circulating level of $\mathrm{F} 3$ than those homozygous for the I allele (26). The $-603 \mathrm{~A} \rightarrow \mathrm{G}$ polymorphism was associated with the abundance of F3 mRNA in monocytes, with individuals with the $G$ allele manifesting a larger amount of F3 mRNA than those with the AA genotype (27). We have now shown that the $-603 \mathrm{~A} \rightarrow \mathrm{G}$ polymorphism of $F 3$ is significantly associated with the prevalence of type 2 diabetes mellitus, with the $-603 \mathrm{G}$ allele being a risk factor for this condition. This is the first demonstration of an association of a polymorphism of $F 3$ with type 2 diabetes mellitus, although the underlying molecular mechanism remains to be elucidated. Our finding is consistent with previous observations that the levels of F3 in plasma and in various types of cells are increased in diabetic subjects, that increased levels of F3 are deleterious in terms of vascular complications in diabetic individuals and for islet transplantation, and that the $G$ allele of the- $603 \mathrm{~A} \rightarrow \mathrm{G}$ polymorphism is related to increased expression of F3 (20-23,25).

Given the multiple comparisons of genotypes with type 2 diabetes mellitus in the present study, we adopted a strict criterion $(p<0.001)$ for statistical significance of association.
It is not possible, however, to exclude completely potential statistical errors such as false positives. It is also possible that the $-603 \mathrm{~A} \rightarrow \mathrm{G}$ polymorphism of $F 3$ is in linkage disequilibrium with polymorphisms of other nearby genes that are actually responsible for the development of type 2 diabetes mellitus. The functional relevance of the $-603 \mathrm{~A} \rightarrow \mathrm{G}$ polymorphism of $F 3$ to the pathophysiology of type 2 diabetes mellitus was also not examined in the present study. Despite these limitations, our present results suggest that $F 3$ is a susceptibility locus for type 2 diabetes mellitus in the Japanese population. Determination of genotype for this polymorphism may prove informative for assessment of the genetic risk for type 2 diabetes mellitus and may contribute to the personalized prevention of this condition.

\section{Acknowledgments}

This work was supported in part by a Grant-in-Aid for Scientific Research from the Ministry of Education, Culture, Sports, Science, and Technology of Japan (no. 15209021, to Y.Y.) and by a grant from Gifu Prefectural Science and Technology Promotion Center (to Y.Y.).

In addition to the authors, the following investigators and Japanese institutions participated in the study: Y. Matsuno and M. Tomita (Gifu Prefectural Gifu Hospital, Gifu); T. Hibino and M. Oguri (Gifu Prefectural Tajimi Hospital, Tajimi); S. Tanihata (Gifu Prefectural Gero Hotspring Hospital, Gero); M. Hiramoto (Hirosaki University, Hirosaki); and nursing and laboratory staff in the participating hospitals.

\section{References}

1. Hanis CL, Boerwinkle E, Chakraborty R, et al: A genome-wide search for human non-insulin-dependent (type 2) diabetes genes reveals a major susceptibility locus on chromosome 2 . Nat Genet 13: 161-166, 1996.

2. Mahtani MM, Widen E, Lehto M, et al: Mapping of a gene for type 2 diabetes associated with an insulin secretion defect by a genome scan in Finnish families. Nat Genet 14: 90-94, 1996.

3. Elbein SC, Hoffman MD, Teng K, Leppert MF and Hasstedt SJ: A genome-wide search for type 2 diabetes susceptibility genes in Utah Caucasians. Diabetes 48: 1175-1182, 1999.

4. Ghosh S, Watanabe RM, Hauser ER, et al: Type 2 diabetes: evidence for linkage on chromosome 20 in 716 Finnish affected sib pairs. Proc Natl Acad Sci USA 96: 2198-2203, 1999.

5. Vionnet N, Hani El-H, Dupont S, et al: Genomewide search for type 2 diabetes-susceptibility genes in French whites: evidence for a novel susceptibility locus for early-onset diabetes on chromosome 3q27-qter and independent replication of a type 2diabetes locus on chromosome 1q21-q24. Am J Hum Genet 67: $1470-1480,2000$

6. Vionnet N, Stoffel M, Takeda J, et al: Nonsense mutation in the glucokinase gene causes early-onset non-insulin-dependent diabetes mellitus. Nature 356: 721-722, 1992.

7. Almind K, Bjorbaek C, Vestergaard H, Hansen T, Echwald S and Pedersen O: Amino acid polymorphisms of insulin receptor substrate-1 in non-insulin-dependent diabetes mellitus. Lancet 342: 828-832, 1993

8. Altshuler D, Hirschhorn JN, Klannemark M, et al: The common PPAR $\gamma$ Pro12Ala polymorphism is associated with decreased risk of type 2 diabetes. Nat Genet 26: 76-80, 2000.

9. Horikawa Y, Oda N, Cox NJ, et al: Genetic variation in the gene encoding calpain-10 is associated with type 2 diabetes mellitus. Nat Genet 26: 163-175, 2000.

10. Hara K, Boutin P, Mori Y, et al: Genetic variation in the gene encoding adiponectin is associated with an increased risk of type 2 diabetes in the Japanese population. Diabetes 51: 536-540, 2002. 
11. The Expert Committee on the Diagnosis and Classification of Diabetes Mellitus: Report of the Expert Committee on the Diagnosis and Classification of Diabetes Mellitus. Diabetes Care 21: S5-S19, 1998

12. Kuzuya T, Nakagawa S, Satoh J, et al: Report of the Committee on the Classification and Diagnosis Criteria of Diabetes Mellitus. Diabetes Res Clin Pract 55: 65-85, 2002.

13. Itoh Y, Mizuki N, Shimada T, et al: High-throughput DNA typing of HLA-A, -B, -C, and -DRB1 loci by a PCR-SSOPLuminex method in the Japanese population. Immunogenetics 57: 717-729, 2005

14. Ehm MG, Karnoub MC, Sakul H, et al: American Diabetes Association GENNID Study Group: Genetics of NIDDM. Genomewide search for type 2 diabetes susceptibility genes in four American populations. Am J Hum Genet 66: 1871-1881, 2000.

15. Mori Y, Otabe S, Dina C, et al: Genome-wide search for type 2 diabetes in Japanese affected sib-pairs confirms susceptibility genes on $3 q, 15 q$, and $20 q$ and identifies two new candidate loci on 7p and 11p. Diabetes 51: 1247-1255, 2002.

16. Iwasaki N, Cox NJ, Wang YQ, et al: Mapping genes influencing type 2 diabetes risk and BMI in Japanese subjects. Diabetes 52: 209-213, 2003

17. Mackman N: Regulation of the tissue factor gene. FASEB J 9: 883-889, 1995

18. Samad F, Pandey M and Loskutoff DJ: Tissue factor gene expression in the adipose tissues of obese mice. Proc Natl Acad Sci USA 95: 7591-7596, 1998.

19. Samad F, Pandey M and Loskutoff DJ: Regulation of tissue factor gene expression in obesity. Blood 98: 3353-3358, 2001.

20. Ichikawa K, Yoshinari M, Iwase M, et al: Advanced glycosylation end products induced tissue factor expression in human monocyte-like U937 cells and increased tissue factor expression in monocytes from diabetic patients. Atherosclerosis 136: 281-287, 1998.
21. Diamant M, Nieuwland R, Pablo RF, Sturk A, Smit JW and Radder JK: Elevated numbers of tissue-factor exposing microparticles correlate with components of the metabolic syndrome in uncomplicated type 2 diabetes mellitus. Circulation 106: 2442-2447, 2002.

22. Lim HS, Blann AD and Lip GY: Soluble CD40 ligand, soluble P-selectin, interleukin-6, and tissue factor in diabetes mellitus: relationships to cardiovascular disease and risk factor intervention. Circulation 109: 2524-2528, 2004

23. Lim HS, Chong AY, Freestone B, Blann AD and Lip GY: The effect of multi-factorial intervention on plasma von Willebrand factor, soluble E-selectin and tissue factor in diabetes mellitus: implications for atherosclerotic vascular disease. Diabet Med 22: 249-255, 2005.

24. Ott I, Koch W, von Beckerath N, et al: Tissue factor promoter polymorphism $-603 \mathrm{~A} / \mathrm{G}$ is associated with myocardial infarction. Atherosclerosis 177: 189-191,2004.

25. Moberg L, Johansson H, Lukinius A, et al: Production of tissue factor by pancreatic islet cells as a trigger of detrimental thrombotic reactions in clinical islet transplantation. Lancet 360: 2039-2045, 2002.

26. Arnaud E, Barbalat V, Nicaud V, et al: Polymorphisms in the $5^{\prime}$ regulatory region of the tissue factor gene and the risk of myocardial infarction and venous thromboembolism: the ECTIM and PATHROS studies. Etude Cas-Temoins de l'Infarctus du Myocarde. Paris Thrombosis Case-Control Study. Arterioscler Thromb Vasc Biol 20: 892-898, 2000.

27. Reny JL, Laurendeau I, Fontana P, et al: The TF-603A $\rightarrow$ G gene promoter polymorphism and circulating monocyte tissue factor gene expression in healthy volunteers. Thromb Haemost 91 248-254, 2004.

Supplementary Table I. The 148 polymorphisms examined in the study.

\begin{tabular}{|c|c|c|c|c|}
\hline Locus & Gene & Symbol & Polymorphism & dbSNPa \\
\hline $1 \mathrm{p} 36.3$ & 5,10-Methylenetetrahydrofolate reductase & MTHFR & $677 \mathrm{C} \rightarrow \mathrm{T}($ Ala222Val) & rs1801133 \\
\hline $1 \mathrm{p} 36$ & Urotensin II & UTS2 & $347 \mathrm{G} \rightarrow \mathrm{A}($ Ser89Asn $)$ & rs2890565 \\
\hline $1 \mathrm{p} 34.2$ & Polycystic kidney disease 1-like & PKDl-like & $\mathrm{G} \rightarrow \mathrm{A}(\mathrm{Gly} 243 \mathrm{Asp})$ & rs1635712 \\
\hline $1 \mathrm{p} 34.1-\mathrm{p} 32$ & Proprotein convertase, subtilisin/kexin-type, 9 & PCSK9 & 23968A $\rightarrow$ G (Glu670Gly) & rs505151 \\
\hline $1 \mathrm{p} 22-\mathrm{p} 21$ & Coagulation factor III & $F 3$ & $-603 \mathrm{~A} \rightarrow \mathrm{G}$ & rs1361600 \\
\hline $1 \mathrm{p} 22.1$ & Glutamate-cysteine ligase, modifier subunit & GCLM & $-588 \mathrm{C} \rightarrow \mathrm{T}$ & (U72210) \\
\hline $1 q 23-q 25$ & Selectin E & SELE & $561 \mathrm{~A} \rightarrow \mathrm{C}(\operatorname{Ser} 128 \mathrm{Arg})$ & rs5361 \\
\hline $1 q 23-q 25$ & Selectin P & SELP & $\mathrm{G} \rightarrow \mathrm{T}(\mathrm{Val640Leu})$ & rs6133 \\
\hline $1 q 25$ & Tumor necrosis factor ligand superfamily, member 4 & TNFSF4 & $\mathrm{A} \rightarrow \mathrm{G}$ & rs3850641 \\
\hline $1 \mathrm{q} 31-\mathrm{q} 32$ & Interleukin 10 & IL10 & $-819 \mathrm{~T} \rightarrow \mathrm{C}$ & rs1800871 \\
\hline $1 \mathrm{q} 31-\mathrm{q} 32$ & Interleukin 10 & IL10 & $-592 \mathrm{~A} \rightarrow \mathrm{C}$ & rs1800872 \\
\hline $1 q 42-q 43$ & Angiotensinogen & $A G T$ & $-6 \mathrm{G} \rightarrow \mathrm{A}$ & rs5051 \\
\hline
\end{tabular}


Supplementary Table I. Continued.

\begin{tabular}{|c|c|c|c|c|}
\hline Locus & Gene & Symbol & Polymorphism & $\mathrm{dbSNP}^{\mathrm{a}}$ \\
\hline $2 q 14$ & Interleukin $1-\beta$ & $I L 1 B$ & $-511 \mathrm{C} \rightarrow \mathrm{T}$ & rs 16944 \\
\hline $2 q 36$ & Insulin receptor substrate 1 & IRS1 & $3931 \mathrm{G} \rightarrow \mathrm{A}(\mathrm{Gly} 972 \mathrm{Arg})$ & rs 1801278 \\
\hline $2 \mathrm{q} 37.3$ & Calpain 10 & CAPN10 & $4852 \mathrm{G} \rightarrow \mathrm{A}$ & rs 3792267 \\
\hline 3 pter-p21 & Chemokine, $\mathrm{CX} 3 \mathrm{C}$ motif, receptor 1 & $C X 3 C R 1$ & $926 \mathrm{C} \rightarrow \mathrm{T}(\mathrm{Thr} 280 \mathrm{Met})$ & rs3732378 \\
\hline $3 p 25$ & Peroxisome proliferator-activated receptor- $\gamma$ & $P P A R G$ & $-681 C \rightarrow G$ & rs 10865710 \\
\hline $3 p 25$ & Peroxisome proliferator-activated receptor- $\gamma$ & & $34 \mathrm{C} \rightarrow \mathrm{G}$ (Pro12Ala) & rs 1801282 \\
\hline $3 p 22$ & Transforming growth factor- $ß$ receptor, type II & TGFBR2 & $1167 \mathrm{C} \rightarrow \mathrm{T}($ Asn389Asn $)$ & rs 2228048 \\
\hline $3 \mathrm{p} 22-\mathrm{p} 21.3$ & Phospholipase C, $\delta-1$ & PLCD1 & $864 \mathrm{G} \rightarrow \mathrm{A}($ (Arg257His) & rs933135 \\
\hline $3 \mathrm{p} 21.3$ & Glutathione peroxidase & $G P X 1$ & $\mathrm{C} \rightarrow \mathrm{T}$ (Pro198Leu) & rs 1050450 \\
\hline $3 \mathrm{p} 21$ & Chemokine, CC motif, receptor 2 & CCR2 & $190 \mathrm{G} \rightarrow \mathrm{A}($ Val64Ile $)$ & rs1799864 \\
\hline $3 \mathrm{p} 21$ & Chemokine, CC motif, receptor 5 & CCR5 & $59029 \mathrm{G} \rightarrow \mathrm{A}$ & rs1799987 \\
\hline $3 q 21-q 25$ & Angiotensin receptor 1 & AGTR1 & $1166 \mathrm{~A} \rightarrow \mathrm{C}$ & rs5186 \\
\hline $3 q 21-q 25$ & Angiotensin receptor 1 & AGTR1 & $\mathrm{G} \rightarrow \mathrm{A}($ Ala163Thr $)$ & rs12721226 \\
\hline $3 q 24-q 25$ & Purinergic receptor $\mathrm{P} 2 \mathrm{Y}, \mathrm{G}$ protein-coupled, 12 & $P 2 R Y 12$ & $744 \mathrm{~T} \rightarrow \mathrm{C}$ & (NC_000003) \\
\hline $3 q 26.1-q 26.2$ & Butyrylcholinesterase & $B C H E$ & $1615 \mathrm{G} \rightarrow \mathrm{A}(\mathrm{Ala539Thr})$ & rs 1803274 \\
\hline $3 q 26.3-q 27$ & Thrombopoietin & THPO & $5713 \mathrm{~A} \rightarrow \mathrm{G}$ & rs6141 \\
\hline $3 q 27$ & Adipocyte, $\mathrm{C} 1 \mathrm{Q}$, and collagen domain containing & $A C D C$ & $-11377 \mathrm{C} \rightarrow \mathrm{G}$ & rs266729 \\
\hline $3 q 28$ & Adaptor-related protein complex 2, MU-1 subunit & $A P 2 M 1$ & $62 \mathrm{G} \rightarrow \mathrm{T}$ & rs 1501299 \\
\hline $4 \mathrm{p} 15.1$ & Peroxisome proliferator-activated receptor- $\gamma$, coactivator 1 & PPARGC1 & $1564 \mathrm{G} \rightarrow \mathrm{A}(\mathrm{Gly} 482 \mathrm{Ser})$ & rs8192678 \\
\hline $4 q 22-q 24$ & Microsomal triglyceride transfer protein, $88-\mathrm{kD}$ & MTP & $-493 \mathrm{G} \rightarrow \mathrm{T}$ & rs1800591 \\
\hline $4 q 26-q 28$ & Annexin A5 & ANXA5 & $-1 \mathrm{C} \rightarrow \mathrm{T}$ & rs11575945 \\
\hline $4 q 28-q 31$ & Fatty acid-binding protein 2 & $F A B P 2$ & 2445G $\rightarrow$ A (Ala54Thr $)$ & rs1799883 \\
\hline $4 q 31$ & Uncoupling protein 1 & $U C P 1$ & $-112 \mathrm{~A} \rightarrow \mathrm{C}$ & rs 10011540 \\
\hline $4 \mathrm{q} 31.22$ & Endothelin receptor, type A & EDNRA & $-231 \mathrm{~A} \rightarrow \mathrm{G}$ & rs1801708 \\
\hline $5 q 12$ & Phosphodiesterase 4D, cAMP-specific & $P D E 4 D$ & TAAA $\rightarrow-\left(3^{\prime}-\right.$ UTR $)$ & rs3839219 \\
\hline $5 q 13$ & Thrombospondin IV & THBS4 & $1186 \mathrm{G} \rightarrow \mathrm{C}$ (Ala387Pro) & rs1866389 \\
\hline $5 q 13$ & Phosphatidylinositol 3-kinase, regulatory, 1 & PIK3R1 & $1020 \mathrm{G} \rightarrow \mathrm{A}($ Met326Ile $)$ & rs 3730089 \\
\hline $5 q 23-q 31$ & Integrin, $\alpha-2$ & ITGA2 & $1648 \mathrm{~A} \rightarrow \mathrm{G}($ Lys505Glu $)$ & rs10471371 \\
\hline $5 \mathrm{q} 31.1$ & Monocyte differentiation antigen CD14 & $C D 14$ & $-260 \mathrm{C} \rightarrow \mathrm{T}$ & rs 2569190 \\
\hline $5 q 32-q 34$ & ß-2-adrenergic receptor & $A D R B 2$ & $46 \mathrm{~A} \rightarrow \mathrm{G}(\operatorname{Arg} 16 \mathrm{Gly})$ & rs 1042713 \\
\hline $5 q 32-q 34$ & $ß$-2-adrenergic receptor & $A D R B 2$ & $79 \mathrm{C} \rightarrow \mathrm{G}(\mathrm{G} \ln 27 \mathrm{Glu})$ & rs 1042714 \\
\hline $5 q 33-q$ ter & Factor XII & $F 12$ & $46 \mathrm{C} \rightarrow \mathrm{T}$ & rs17876008 \\
\hline 6 p24-p23 & Endothelin 1 & EDN1 & $5665 \mathrm{G} \rightarrow \mathrm{T}($ Lys198Asn $)$ & rs5370 \\
\hline $6 \mathrm{p} 21.3$ & Lymphotoxin- $\alpha$ & $L T A$ & $804 \mathrm{C} \rightarrow \mathrm{A}$ (Thr26Asn) & rs2229093 \\
\hline $6 \mathrm{p} 21.3$ & Tumor necrosis factor & $T N F$ & $-863 \mathrm{C} \rightarrow \mathrm{A}$ & rs1800630 \\
\hline $6 \mathrm{p} 21.3$ & Tumor necrosis factor & $T N F$ & $-850 \mathrm{C} \rightarrow \mathrm{T}$ & rs1799724 \\
\hline $6 \mathrm{p} 21.3$ & Tumor necrosis factor & $T N F$ & $-238 \mathrm{G} \rightarrow \mathrm{A}$ & rs 361525 \\
\hline $6 \mathrm{p} 21.3$ & Advanced glycosylation end product-specific receptor & $A G E R$ & $268 \mathrm{G} \rightarrow \mathrm{A}($ Gly82Ser $)$ & rs 2070600 \\
\hline $6 \mathrm{p} 21.2-\mathrm{p} 21.1$ & Peroxisome proliferator-activated receptor- $\delta$ & PPARD & 294T_C & rs 2016520 \\
\hline $6 \mathrm{p} 21.2-\mathrm{p} 12$ & Phospholipase A2, group VII & $P L A 2 G 7$ & 994G $\rightarrow \mathrm{T}$ (Val279Phe) & rs16874954 \\
\hline $6 \mathrm{p} 12$ & Glutamate-cysteine ligase, catalytic subunit & $G C L C$ & $-129 \mathrm{C} \rightarrow \mathrm{T}$ & rs17883901 \\
\hline $6 \mathrm{p} 12$ & Vascular endothelial growth factor & $V E G F$ & $936 \mathrm{C} \rightarrow \mathrm{T}$ & rs3025039 \\
\hline $6 q 22-q 23$ & Ectonucleotide pyrophosphatase/phosphodiesterase 1 & ENPP1 & $97 \mathrm{~A} \rightarrow \mathrm{C}($ Lys 121Gln $)$ & rs 1044498 \\
\hline $6 \mathrm{q} 25.1$ & Estrogen receptor 1 & ESR1 & $-1989 \mathrm{~T} \rightarrow \mathrm{G}$ & rs2071454 \\
\hline $6 q 27$ & Thrombospondin II & THBS2 & $3949 \mathrm{~T} \rightarrow \mathrm{G}$ & rs8089 \\
\hline $7 \mathrm{p} 21$ & Interleukin 6 & IL6 & $-572 \mathrm{G} \rightarrow \mathrm{C}$ & rs1800796 \\
\hline $7 \mathrm{p} 15-\mathrm{p} 13$ & Glucokinase & $G C K$ & $-30 \mathrm{G} \rightarrow \mathrm{A}$ & (M90297) \\
\hline $7 q 11.2$ & Syntaxin $1 \mathrm{~A}$ & STX1A & $205 \mathrm{~T} \rightarrow \mathrm{C}($ Asp68Asp $)$ & rs 2293485 \\
\hline
\end{tabular}


Supplementary Table I. Continued.

\begin{tabular}{|c|c|c|c|c|}
\hline Locus & Gene & Symbol & Polymorphism & $\mathrm{dbSNP}^{\mathrm{a}}$ \\
\hline $7 \mathrm{q} 11.2$ & CD36 antigen & $C D 36$ & $30294 \mathrm{G} \rightarrow \mathrm{C}$ & rs1049673 \\
\hline $7 q 11.23-q 21.11$ & Protein phosphatase 1 , regulatory subunit $3 \mathrm{~A}$ & $P P P 1 R 3 A$ & $2647 \mathrm{G} \rightarrow \mathrm{T}(\mathrm{Ser} 883 \mathrm{Arg})$ & $(\mathrm{X} 78578)$ \\
\hline $7 q 11.23-q 21.11$ & Protein phosphatase 1 , regulatory subunit $3 \mathrm{~A}$ & $P P P 1 R 3 A$ & $2711 \mathrm{G} \rightarrow \mathrm{T}$ (Tyr905Asp) & rs1799999 \\
\hline $7 \mathrm{q} 21.3$ & Paraoxonase 1 & PON1 & $-162 \mathrm{G} \rightarrow \mathrm{A}$ & rs705381 \\
\hline $7 q 21.3$ & Paraoxonase 1 & PON1 & $532 \mathrm{~A} \rightarrow \mathrm{G}$ (Arg160Gly) & rs13306698 \\
\hline $7 \mathrm{q} 21.3$ & Paraoxonase 1 & PON1 & $584 \mathrm{G} \rightarrow \mathrm{A}(\mathrm{Gln} 192 \mathrm{Arg})$ & rs662 \\
\hline $7 \mathrm{q} 21.3$ & Paraoxonase 2 & PON2 & $475 \mathrm{C} \rightarrow \mathrm{G}$ (Ala148Gly) & rs11545941 \\
\hline $7 q 21.3-q 22$ & Plasminogen activator inhibitor 1 & PAII & $-668 / 4 \mathrm{G} \rightarrow 5 \mathrm{G}$ & rs1799768 \\
\hline $7 q 21.3-q 22$ & Plasminogen activator inhibitor 1 & PAII & $\mathrm{A} \rightarrow \mathrm{G}$ (Tyr243Cys) & rs13306846 \\
\hline $7 \mathrm{q} 32$ & Paired box gene 4 & PAX4 & $567 \mathrm{C} \rightarrow \mathrm{T}(\operatorname{Arg} 121 \mathrm{Trp})$ & $(\mathrm{AF} 043978)$ \\
\hline $7 \mathrm{q} 36$ & Nitric oxide synthase 3 & NOS3 & $-786 \mathrm{~T} \rightarrow \mathrm{C}$ & rs2070744 \\
\hline $8 \mathrm{p} 22$ & Lipoprotein lipase & $L P L$ & $1595 \mathrm{C} \rightarrow \mathrm{G}$ (Ser447Stop) & rs 328 \\
\hline $8 \mathrm{p} 21-\mathrm{p} 12$ & Epoxide hydrolase 2, cytosolic & EPHX2 & $\mathrm{G} \rightarrow \mathrm{A}(\mathrm{Arg} 287 \mathrm{Gln})$ & rs751141 \\
\hline $8 \mathrm{p} 12$ & Plasminogen activator, tissue & PLAT & $-7351 \mathrm{C} \rightarrow \mathrm{T}$ & rs2020918 \\
\hline 8p12-p11.2 & ß-3-adrenergic receptor & $A D R B 3$ & 190T $\rightarrow C$ (Trp64Arg) & rs4994 \\
\hline 8p12-p11.2 & RecQ protein-like 2 & RECQL2 & $47765 \mathrm{~T} \rightarrow \mathrm{C}(\mathrm{Cys} 1367 \mathrm{Arg})$ & rs1346044 \\
\hline $9 q 22-q 31$ & ATP-binding cassette, subfamily A, member 1 & $A B C A 1$ & $1051 \mathrm{G} \rightarrow \mathrm{A}(\mathrm{Arg} 219 \mathrm{Lys})$ & rs2230806 \\
\hline $9 q 22-q 31$ & ATP-binding cassette, subfamily A, member 1 & $A B C A 1$ & $2583 \mathrm{~A} \rightarrow \mathrm{G}$ (Ile823Met) & rs4149313 \\
\hline $9 q 34.1$ & Endoglin & $E N G$ & $1691 \mathrm{C} \rightarrow \mathrm{G}$ (Asp366His) & rs1800956 \\
\hline $9 q 34.2-q 34.3$ & Prostaglandin D2 synthase, brain & PTGDS & $4111 \mathrm{~A} \rightarrow \mathrm{C}$ & rs6926 \\
\hline $10 \mathrm{q} 11.2$ & Arachidonate 5-lipoxygenase & ALOX5 & $\mathrm{G} \rightarrow \mathrm{A}($ Glu254Lys $)$ & rs2228065 \\
\hline $10 q 24-q 26$ & ß-1-adrenergic receptor & $A D R B 1$ & $1165 \mathrm{G} \rightarrow \mathrm{C}(\mathrm{Gly} 389 \mathrm{Arg})$ & rs1801253 \\
\hline $11 \mathrm{p} 15.5$ & Insulin & $I N S$ & $-23 \mathrm{~T} \rightarrow \mathrm{A}$ & rs 689 \\
\hline $11 \mathrm{p} 15.1$ & Potassium channel, inwardly rectifying, subfamily $\mathrm{J}$, member 11 & KCNJ11 & $276 \mathrm{~A} \rightarrow \mathrm{G}$ (Glu23Lys) & rs5219 \\
\hline $11 \mathrm{p} 15.1$ & ATP-binding cassette, subfamily $\mathrm{C}$, member 8 & $A B C C 8$ & $3857 \mathrm{G} \rightarrow \mathrm{A}(\operatorname{Arg} 1273 \mathrm{Arg})$ & rs4148643 \\
\hline $11 \mathrm{q} 13$ & Uncoupling protein 2 & $U C P 2$ & $-866 \mathrm{G} \rightarrow \mathrm{A}$ & rs659366 \\
\hline $11 \mathrm{q} 13$ & Uncoupling protein 3 & $U C P 3$ & $-55 \mathrm{C} \rightarrow \mathrm{T}$ & rs1800849 \\
\hline $11 \mathrm{q} 22.2-\mathrm{q} 22.3$ & Matrix metalloproteinase 12 & $M M P 12$ & $-82 \mathrm{~A} \rightarrow \mathrm{G}$ & rs2276109 \\
\hline $11 q 22-q 23$ & Matrix metalloproteinase 1 & $M M P 1$ & $-1607 / 1 \mathrm{G} \rightarrow 2 \mathrm{G}$ & rs1799750 \\
\hline $11 \mathrm{q} 23$ & Apolipoprotein A-I & APOAl & $-75 \mathrm{G} \rightarrow \mathrm{A}$ & rs670 \\
\hline $11 \mathrm{q} 23$ & Apolipoprotein A-I & APOAI & $84 \mathrm{~T} \rightarrow \mathrm{C}$ & rs 5070 \\
\hline $11 q 23$ & Apolipoprotein A-V & APOA5 & $-1131 \mathrm{~T} \rightarrow \mathrm{C}$ & rs662799 \\
\hline $11 \mathrm{q} 23$ & Apolipoprotein C-III & АРОC 3 & $-482 \mathrm{C} \rightarrow \mathrm{T}$ & rs2854117 \\
\hline $11 \mathrm{q} 23$ & Apolipoprotein C-III & АРОС 3 & $1100 \mathrm{C} \rightarrow \mathrm{T}$ & rs 4520 \\
\hline $11 \mathrm{q} 23$ & Matrix metalloproteinase 3 & MMP3 & $-1171 / 5 \mathrm{~A} \rightarrow 6 \mathrm{~A}$ & rs3025058 \\
\hline $11 \mathrm{q} 23$ & Matrix metalloproteinase 3 & MMP3 & $\mathrm{A} \rightarrow \mathrm{G}($ Lys $45 \mathrm{Glu})$ & rs679620 \\
\hline $11 \mathrm{q} 23.3-\mathrm{q} 25$ & Heat-shock $70-\mathrm{kD}$ protein 8 & HSPA8 & $-110 \mathrm{~A} \rightarrow \mathrm{C}$ & rs1008438 \\
\hline $12 \mathrm{p} 13$ & Guanine nucleotide-binding protein, $\beta-3$ & GNB3 & $825 \mathrm{C} \rightarrow \mathrm{T}$ (splice variant) & rs5443 \\
\hline $12 \mathrm{p} 13-\mathrm{p} 12$ & Low density lipoprotein, oxidized, receptor 1 & OLRI & $501 \mathrm{G} \rightarrow \mathrm{C}($ Lys167Asn $)$ & rs11053646 \\
\hline $13 \mathrm{q} 12.1$ & Insulin promoter factor 1 & $I P F 1$ & $-108 / 3 \mathrm{G} \rightarrow 4 \mathrm{G}$ & (S82168) \\
\hline $13 q 14.11$ & Carboxypeptidase B2, plasma & $C P B 2$ & $529 \mathrm{G} \rightarrow \mathrm{A}($ Ala147Thr $)$ & rs3742264 \\
\hline $13 q 14.11$ & Carboxypeptidase B2, plasma & $C P B 2$ & $\mathrm{~T} \rightarrow \mathrm{C}(\mathrm{Ile} 347 \mathrm{Thr})$ & rs1926447 \\
\hline $13 q 34$ & Factor VII & F7 & $11496 \mathrm{G} \rightarrow \mathrm{A}(\mathrm{Arg} 353 \mathrm{Gln})$ & rs6046 \\
\hline $14 \mathrm{q} 11.2$ & Cathepsin G & CTSG & $2108 \mathrm{~A} \rightarrow \mathrm{G}($ Asn125Ser $)$ & (J04990) \\
\hline $14 \mathrm{q} 32.1$ & $\alpha$-1-antichymotrypsin & $A A C T$ & $50 \mathrm{G} \rightarrow \mathrm{A}($ Ala15Thr $)$ & rs4934 \\
\hline $14 \mathrm{q} 32.1-\mathrm{q} 32.2$ & Bradykinin receptor B2 & $B D K R B 2$ & $\mathrm{C} \rightarrow \mathrm{T}(\operatorname{Arg} 14 \mathrm{Cys})$ & rs1046248 \\
\hline $15 q 21-q 23$ & Lipase, hepatic & $L I P C$ & $-250 \mathrm{G} \rightarrow \mathrm{A}$ & rs2070895 \\
\hline
\end{tabular}


Supplementary Table I. Continued.

\begin{tabular}{|c|c|c|c|c|}
\hline Locus & Gene & Symbol & Polymorphism & dbSNPa \\
\hline $16 \mathrm{p} 13$ & Major histocompatibility complex, class II, transactivator & MHC2TA & $-168 \mathrm{~A} \rightarrow \mathrm{G}$ & rs3087456 \\
\hline $16 \mathrm{q} 13$ & Matrix metalloproteinase 2 & $M M P 2$ & $-1306 \mathrm{C} \rightarrow \mathrm{T}$ & rs243865 \\
\hline $16 \mathrm{q} 21$ & Cholesteryl ester transfer protein, plasma & CETP & $-629 \mathrm{C} \rightarrow \mathrm{A}$ & rs 1800775 \\
\hline $16 \mathrm{q} 21$ & Cholesteryl ester transfer protein, plasma & CETP & $1061 \mathrm{~A} \rightarrow \mathrm{G}(\mathrm{Ile} 405 \mathrm{Val})$ & rs5882 \\
\hline $16 \mathrm{q} 24$ & Cytochrome b(-245), $\alpha$ subunit & $C Y B A$ & $242 \mathrm{C} \rightarrow \mathrm{T}$ (His72Tyr) & rs4673 \\
\hline 17 pter-p12 & Glycoprotein $\mathrm{Ib}$, platelet, $\alpha$ polypeptide & $G P 1 B A$ & $-5 \mathrm{~T} \rightarrow \mathrm{C}$ & rs2243093 \\
\hline 17 pter-p12 & Glycoprotein $\mathrm{Ib}$, platelet, $\alpha$ polypeptide & $G P 1 B A$ & $1018 \mathrm{C} \rightarrow \mathrm{T}(\mathrm{Thr} 145 \mathrm{Met})$ & rs 6065 \\
\hline $17 \mathrm{p} 13$ & Chemokine, CXC motif, ligand 16 & CXCL16 & $\mathrm{C} \rightarrow \mathrm{T}(\mathrm{Ala} 181 \mathrm{Val})$ & rs2277680 \\
\hline $17 \mathrm{p} 11.2$ & Sterol regulatory element-binding transcription factor 1 & SREBF1 & $-36 \mathrm{G} \rightarrow-$ & $(\mathrm{AX} 977070)$ \\
\hline $17 \mathrm{p} 11.1$ & A-kinase anchoring protein 10 & AKAP10 & $2073 \mathrm{~A} \rightarrow \mathrm{G}(\mathrm{Ile} 646 \mathrm{Val})$ & rs203462 \\
\hline $17 q 11.2-q 12$ & Chemokine, CC motif, ligand 5 & CCL5 & $-28 \mathrm{C} \rightarrow \mathrm{G}$ & rs2280788 \\
\hline $17 q 11.2-q 12$ & Chemokine, CC motif, ligand 5 & $C C L 5$ & $-403 \mathrm{G} \rightarrow \mathrm{A}$ & rs2107538 \\
\hline $17 \mathrm{q} 21.1-\mathrm{q} 21.2$ & Chemokine, CC motif, ligand 11 & $C C L 11$ & $\mathrm{G} \rightarrow \mathrm{A}(\mathrm{Ala} 23 \mathrm{Thr})$ & rs3744508 \\
\hline $17 \mathrm{q} 23$ & Angiotensin I- converting enzyme & $A C E$ & $-240 \mathrm{~A} \rightarrow \mathrm{T}$ & rs4291 \\
\hline $17 \mathrm{q} 23$ & Platelet-endothelial cell adhesion molecule 1 & PECAM1 & $1454 \mathrm{C} \rightarrow \mathrm{G}($ Leu125Val $)$ & rs668 \\
\hline $17 \mathrm{q} 23$ & Platelet-endothelial cell adhesion molecule 1 & PECAM1 & $2201 \mathrm{G} \rightarrow \mathrm{A}(\mathrm{Gly} 670 \mathrm{Arg})$ & rs1131012 \\
\hline 17q23-qter & Apolipoprotein H & $\mathrm{APOH}$ & $341 \mathrm{G} \rightarrow \mathrm{A}($ Ser88Asn $)$ & rs1801692 \\
\hline $18 \mathrm{q} 21.1$ & Lipase, endothelial & $L I P G$ & $584 \mathrm{C} \rightarrow \mathrm{T}(\mathrm{Thr} 111 \mathrm{Ile})$ & rs2000813 \\
\hline $19 \mathrm{p} 13.3$ & Resistin & RETN & $-420 \mathrm{C} \rightarrow \mathrm{G}(\mathrm{C}-180 \mathrm{G})$ & rs 1862513 \\
\hline $19 \mathrm{p} 13.3$ & Resistin & RETN & $-180 \mathrm{C} \rightarrow \mathrm{G}$ & rs 1862513 \\
\hline $19 \mathrm{p} 13.3$ & Resistin & RETN & $+62 \mathrm{G} \rightarrow \mathrm{A}$ & rs3745368 \\
\hline 19p13.3-p13.2 & Intercellular adhesion molecule 1 & ICAM1 & $1462 \mathrm{G} \rightarrow \mathrm{A}($ Glu469Lys $)$ & rs5498 \\
\hline $19 \mathrm{p} 13.2$ & Insulin receptor & $I N S R$ & $7067365 \mathrm{C} \rightarrow \mathrm{A}$ & rs2860172 \\
\hline $19 \mathrm{p} 13.2$ & Low density lipoprotein receptor & $L D L R$ & $1184 \mathrm{G} \rightarrow \mathrm{A}(\mathrm{Ala} 370 \mathrm{Thr})$ & rs11669576 \\
\hline $19 \mathrm{q} 13.1$ & Transforming growth factor, $B-1$ & $T G F B 1$ & $-509 \mathrm{C} \rightarrow \mathrm{T}$ & rs 1800469 \\
\hline $19 \mathrm{q} 13.2$ & Apolipoprotein E & APOE & $-219 \mathrm{G} \rightarrow \mathrm{T}$ & rs405509 \\
\hline $19 \mathrm{q} 13.2$ & Apolipoprotein E & $A P O E$ & $3932 \mathrm{~T} \rightarrow \mathrm{C}(\mathrm{Cys} 112 \mathrm{Arg})$ & rs429358 \\
\hline $19 \mathrm{q} 13.2$ & Apolipoprotein E & APOE & $4070 \mathrm{C} \rightarrow \mathrm{T}(\operatorname{Arg} 158 \mathrm{Cys})$ & rs7412 \\
\hline $19 \mathrm{q} 13.3$ & Glycogen synthase 1 & GYS1 & $260 \mathrm{~A} \rightarrow \mathrm{G}(\mathrm{Met} 416 \mathrm{Val})$ & rs5447 \\
\hline $19 \mathrm{q} 13.4$ & Glycoprotein VI, platelet & GP6 & $13254 \mathrm{~T} \rightarrow \mathrm{C}$ (Ser219Pro) & rs 1613662 \\
\hline $20 \mathrm{p} 11.2$ & Thrombomodulin & $T H B D$ & $2136 \mathrm{C} \rightarrow \mathrm{T}($ Ala455Val $)$ & rs1042579 \\
\hline $20 \mathrm{q} 11.2-\mathrm{q} 13.1$ & Matrix metalloproteinase 9 & MMP9 & $855 \mathrm{G} \rightarrow \mathrm{A}(\mathrm{Arg} 279 \mathrm{Gln})$ & rs2664538 \\
\hline 20q13.11-q13.13 & Prostaglandin I 2 synthase & PTGIS & $1117 \mathrm{C} \rightarrow \mathrm{A}$ & rs6095558 \\
\hline $20 \mathrm{q} 13.31$ & Phosphoenolpyruvate carboxykinase 1 , soluble & PCK1 & $-232 \mathrm{C} \rightarrow \mathrm{G}$ & rs2071023 \\
\hline $21 \mathrm{q} 22.3$ & Integrin, $B-2$ & $I T G B 2$ & $1323 \mathrm{C} \rightarrow \mathrm{T}$ & rs235326 \\
\hline $22 \mathrm{q} 11.2$ & Catechol-O-methyltransferase & COMT & $\mathrm{G} \rightarrow \mathrm{A}($ Val158Met $)$ & rs 4680 \\
\hline $22 \mathrm{q} 12$ & Heme oxygenase 1 & HMOX1 & $-413 \mathrm{~T} \rightarrow \mathrm{A}$ & rs2071746 \\
\hline $22 \mathrm{q} 12$ & Heme oxygenase 1 & HMOX1 & 99G $\rightarrow \mathrm{C}($ Asp7His $)$ & rs2071747 \\
\hline $22 \mathrm{q} 12-\mathrm{q} 13$ & Lectin, garactoside-binding, soluble, 2 & $L G A L S 2$ & $3279 \mathrm{C} \rightarrow \mathrm{T}$ (intron 1$)$ & rs7291467 \\
\hline $\mathrm{Xq} 22-\mathrm{q} 23$ & Angiotensin II receptor, type 2 & AGTR2 & $1675 \mathrm{G} \rightarrow \mathrm{A}$ & rs 1403543 \\
\hline$X q 22-q 23$ & Angiotensin II receptor, type 2 & AGTR2 & $3123 \mathrm{C} \rightarrow \mathrm{A}$ & rs11091046 \\
\hline
\end{tabular}

${ }^{a}$ In instances in which rs numbers in dbSNP were not detected, NCBI GenBank accession numbers are shown in parentheses. 


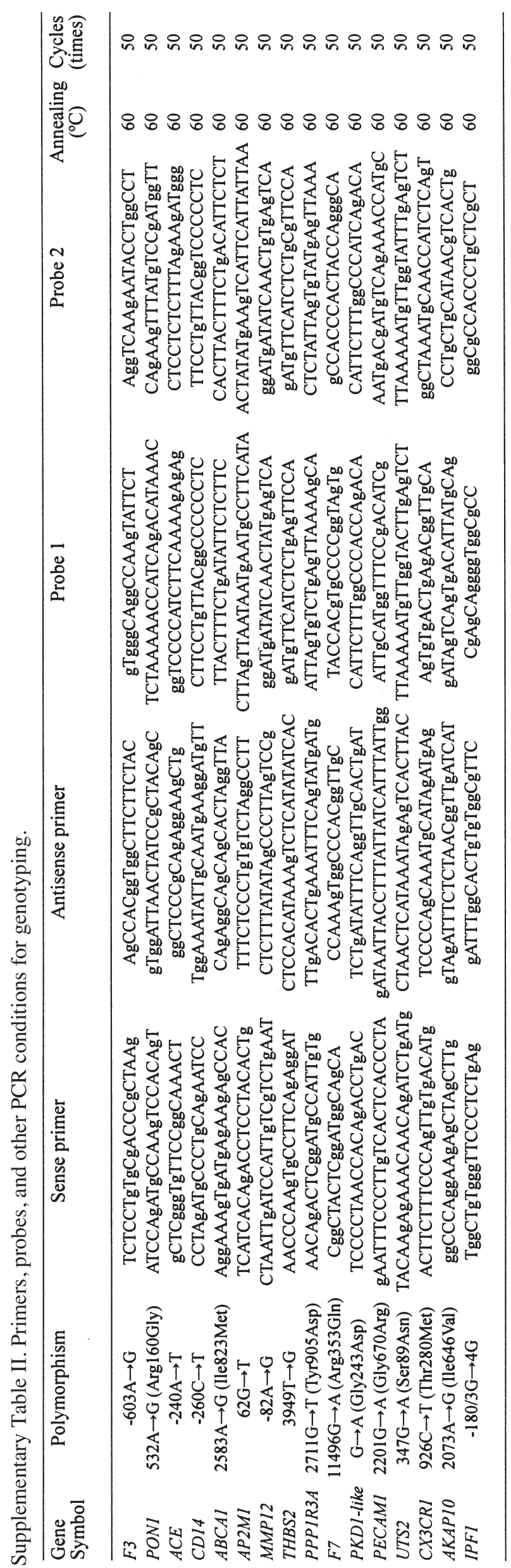

